\title{
CROWDFUNDING: ALTERNATIF PENDANAAN UMKM DAN STARTUP (MODEL PENGGUNAAN UTAUT)
}

\author{
Nur Rahmah Sari \\ Program Studi Akuntansi, Fakultas Ekonomi dan Bisnis Islam Universitas Islam Negeri Alauddin \\ Makassar, Indonesia \\ *e-mail: nur.rahmahsari@uin-alauddin.ac.id
}

\begin{abstract}
ABSTRAK
Menghadapi tantangan berbisnis di dunia digital, dalam beberapa tahun terakhir crowdfunding menjadi salah satu alternatif populer bagi pelaku UMKM dan startup untuk mendapatkan bantuan pendanaan. Penelitian ini dilakukan untuk menguji faktor-faktor yang mempengaruhi pelaku UMKM dan startup dalam memanfaatkan platform crowdfunding sebagai alternatif pendanaan mereka. Penelitian ini mengadopsi model Unified Theory of Acceptance and Use of Technology untuk menguji faktor-faktor tersebut. Data dalam penelitian ini merupakan data primer. Data dikumpulkan melalui penyebaran kuesioner. Responden penelitian merupakan para pelaku UMKM dan startup yang pernah atau sementara mengajukan bantuan pendanaan melalui platform crowdfunding. Analisis data dilakukan melalui uji PLS-SEM. Hasil penelitian menunjukkan bahwa variabel Performance Expectancy dan Social Influence berpengaruh positif terhadap Behavioral Intention dalam penggunaan platform crowdfunding sebagai alternatif pendanaan, sementara variabel Effort Expectancy tidak berpengaruh signifikan. Selain itu, penelitian ini juga menemukan bahwa variabel Facilitating Condition dan Behavioral Intention berpengaruh positif terhadap Use Behavior para pelaku UMKM dan Startup dalam menggunakan platform crowdfunding. Hasil ini menunjukkan adanya kesadaran yang besar dari para pelaku UMKM dan startup untuk beradaptasi dengan perkembangan teknologi informasi yang berkembang pesat di dunia bisnis meskipun membutuhkan usaha (effort) yang cukup besar.
\end{abstract}

\section{Kata Kunci: Crowdfunding, UMKM, Startup}

\section{ABSTRACT}

Facing the challenges of business in digital world, crowdfunding has become one of the popular alternatives for MSMEs and startups to get funding assistance. This study aims to examine the factors that influence SMEs and startups in utilizing crowdfunding platforms as an alternative to their funding. This study adopts the Unified Theory of Acceptance and Use of Technology model to test these factors. The data used in this study are primary data collected through questionnaires. Research respondents are MSME and Startup who have or temporarily submitted funding assistance through the crowdfunding platform. Data analysis was performed through the PLS-SEM test. The results showed that the Performance Expectancy and Social Influence variable have a positive effect on Behavioral Intention in using the crowdfunding platform as an alternative funding, while the Effort Expectancy variable had no significant effect. In addition, this study also found that Facilitating Condition and Behavioral Intention variables have a positive effect on the Use Behavior of MSMEs 
and Startups in using the crowdfunding platform. These results indicate a great awareness of MSMEs and Startups to adapt to the rapidly growing development of information technology in the business world even though it requires considerable effort.

\section{Keywords: Crowdfunding, MSME, Startup}

\section{PENDAHULUAN}

Sebagai upaya menghadapi digitalisasi dalam revolusi industri 4.0, Kementerian Perindustrian Republik Indonesia merancang "Making Indonesia 4.0", sebuah roadmap terintegrasi dalam melaksanakan sejumlah strategi. Jika dilaksanakan dengan baik, program ini diestimasi akan meningkatkan pertumbuhan GDP sebesar 1\%-2\% per tahun dibandingkan dengan baseline pada periode 2018-2030, sehingga berpotensi meningkatkan pertumbuhan ekonomi sebesar 6\%-7\% [1]. Untuk mencapai hal tersebut, diperlukan peran dari berbagai pihak, diantaranya institusi pemerintahan sebagai regulator, akademisi sebagai pencetak SDM yang berkualitas, dan yang paling penting adalah para asosiasi dan pelaku industri/bisnis. Peran UMKM dapat dinilai besar dalam meningkatkan pendapatan dan penyerapan tenaga kerja di Indonesia [2].

Usaha Mikro menyerap kurang lebih 107,2 juta tenaga kerja (89,2\%), terdiri dari Usaha Kecil sebesar 5,7 juta (4,74\%), dan Usaha Menengah sebesar 3,73 juta (3,11\%) [3]. Kepala Biro Perencanaan kementerian Koperasi dan UKM menegaskan bahwa jumlah UMKM terus bertumbuh, yang akhirnya memberikan pengaruh terhadap PDB, dan ini termasuk dari Startup [4]. Meskipun sering dianggap sama, terdapat beberapa perbedaan karakteristik dari UMKM dan Startup. Beberapa karakteristik dari Startup menunjukkan bahwa Startup lebih condong pada perusahaan yang bergerak di bidang teknologi informasi $[5]$.

Dengan mempertimbangkan peran UMKM sebagai penggerak pertumbuhan ekonomi, salah satu upaya pemerintah dalam mewujudkan "making Indonesia 4.0" adalah melalui program UMKM go online. Program ini mendukung para pelaku UMKM untuk memanfaatkan platform online untuk memasarkan produknya. Kementerian Koperasi dan UKM menjelaskan selain memberdayakan UMKM, program ini ditujukan untuk memberi akses pendanaan bagi pelaku bisnis dengan membantu memastikan bahwa produk yang dihasilkan UMKM memiliki kualitas yang mampu bersaing, serta memiliki kapasitas yang cukup, sehingga dapat memperoleh kepercayaan dari sumber pendanaan [6]. Salah satu faktor yang menentukan kesuksesan sebuah Startup adalah funding atau pendanaan [7]. Hal ini lah 
yang seringkali menjadi kendala bagi keberlangsungan dan perkembangan sebuah UMKM dan Startup. Biasanya, bisnis dalam skala kecil cenderung kesulitan dalam mendapatkan pinjaman dari bank. Hal ini dikarenakan kredibilitas peminjam dan kemungkinan untuk mengembalikan yang rendah, serta jaminan aset yang bisa digunakan seandainya peminjam mengalami gagal bayar tidak ada [8].

Dewasa ini, istilah crowdfunding bukan lagi menjadi hal asing bagi para pelaku bisnis. Crowdfunding merupakan metode pendanaan dimana sejumlah dana dikumpulkan dari sekelompok individu atau entitas legal untuk mendanai bisnis, proyek tertentu, kebutuhan individual, dan kebutuhan lainnya [9]. Dari definisi tersebut, dapat disimpulkan bahwa crowdfunding mencakup tiga komponen penting yaitu dana dalam jumlah kecil yang terus meningkat, berasal dari banyak orang dan ditujukan untuk banyak orang/usaha, serta berbasis teknologi digital, biasanya menggunakan platform berbasis web.

Crowdfunding diklasifikasikan dalam empat kategori utama, yaitu Equity Based Crowdfunding, Debt or Credit based Crowdfunding atau peer-to-peer (P2P) Lending, Donation Based Crowdfunding, dan Reward Based Crowdfunding [9], [10]. Meskipun cukup populer, saat ini masih banyak UMKM dan Startup yang belum memutuskan untuk menggunakan platform crowdfunding sebagai alternatif pendanaannya. Minimnya pengetahuan atau informasi mengenai platform crowdfunding bagi para pelaku bisnis UMKM yang didominasi oleh masyarakat kecil menjadi salah satu alasan hal tersebut. Sementara bagi Startup, resiko tidak tercapainya target modal yang diharapkan mungkin menjadi pertimbangan khusus untuk belum mencoba platform crowdfunding. Ditambah lagi, untuk mendapatkan bantuan dana dari platform crowdfunding ini, usaha yang mengajukan pinjaman dituntut untuk membuat campaign yang dapat menarik perhatian pemberi pinjaman.

Penelitian ini dilakukan untuk menguji beberapa yang mempengaruhi pelaku UMKM dan Startup dalam memanfaatkan platform crowdfunding sebagai alternatif pendanaan mereka. Penelitian terkait motivasi dalam menggunakan platform crowdfunding pernah dilakukan sebelumnya dengan melakukan wawancara terhadap 11 informan yang terdiri dari tiga pengaju dana, enam pemberi dana, dan 2 informan lain yang pernah mengajukan dan memberikan dana [11]. Penelitian lain dilakukan untuk menguji faktor-faktor yang memengaruhi masyarakat menyalurkan donasi melalui platform crowdfunding [12]. Meskipun penelitian ini juga dilakukan untuk mengetahui faktor yang memotivasi 
penggunaan platform crowdfunding, penelitian ini dilakukan pada pengaju pinjaman atau pihak yang membutuhkan pendanaan, dalam hal ini yaitu UMKM dan Startup.

Penelitian ini akan mengadopsi model Unified Theory of Acceptance and Use of Technology (UTAUT) untuk menguji faktor-faktor tersebut. Model UTAUT merupakan model gabungan teori penerimaan dan penggunaan teknologi yang mengungkapkan tiga faktor penting yang menentukan minat menggunakan teknologi, yaitu performance expectancy (ekspektasi kinerja), effort expectancy (ekspektasi usaha), serta social influence (pengaruh sosial). Sementara ada dua faktor penentu use behavior (perilaku penggunaan), yaitu behavioral intention (minat) dan facilitating conditions (kondisi-kondisi yang memfasilitasi) [13].

\section{METODE PENELITIAN}

Penelitian ini dilakukan untuk menguji hipotesis yang menjelaskan pengaruh variabel independen terhadap variabel dependen yang digambarkan dalam sebuah model UTAUT. Setelah memperoleh data penelitian, peneliti akan membahas gambaran umum data penelitian yang menjelaskan secara umum karakteristik responden yang berpartisipasi dalam penelitian ini. Kemudian dilakukan uji PLS-SEM dengan melakukan analisis pengukuran model (outer model) dan analisis struktur model (inner model). Hasil uji tersebut kemudian digunakan untuk menyimpulkan apakah hipotesis dalam penelitian bisa diterima atau tidak.

Data dikumpulkan melalui penelitian lapangan berupa survey yang dilakukan melalui penyebaran kuesioner kepada responden. Data dalam kuesioner berisi karakteristik responden, serta tanggapan responden berupa jawaban dari pernyataan-pernyataan yang dikemukakan pada kuesioner. Responden penelitian ini adalah pelaku UMKM dan Startup yang pernah atau sementara mengajukan bantuan pendanaan melalui platform crowdfunding. Butir-butir pernyataan dalam kuesioner dikembangkan disesuaikan dengan variable-variabel yang dalam penelitian berdasarkan model UTAUT [13]. Pernyataan diukur menggunakan 5 poin skala likert yang mewakili jawaban responden, mulai dari poin satu (1) yang merepresentasikan jawaban sangat tidak setuju, hingga poin lima (5) yang merepresentasikan jawaban sangat setuju.

Pengujian hipotesis dalam penelitian ini dilakukan menggunakan model persamaan struktural (Structural Equation Model) atau sering disebut SEM. SEM adalah teknik analisis multivariat generasi kedua dimana analisis faktor dan analisis jalur digabungkan sehingga 
dimungkinkan adanya pengujian dan pengestimasian secara simultan terkait hubungan variabel independen dengan variabel dependen dengan banyak indikator [14]. Dalam penelitian ini, SEM akan diuji menggunakan aplikasi SmartPLS.

\section{HASIL DAN PEMBAHASAN}

\subsection{Hasil Penelitian}

\section{Gambaran Umum Data Penelitian}

Responden dalam penelitian ini terdiri dari 132 pelaku usaha UMKM dan Startup yang pernah atau sementara mengajukan bantuan pendanaan melalui platform crowdfunding. Penelitian dilakukan melalui penyebaran kuesioner. Kuesioner disebarkan dengan dua cara. Penyebaran kuesioner secara langsung dilakukan dengan membagikan kuesioner melalui tatap muka kepada para pelaku usaha UMKM, sementara penyebaran tidak langsung dilakukan dengan membuat kuesioner di google form dan membagikan link untuk pengisian kuesioner tersebut melalui media sosial.

\section{Analisis Pengukuran Model (Outer Model)}

\section{Uji Individual Item Reliability}

Dalam tahap pengujian ini, dilakukan peninjauan nilai Standardized Loading Factor. Nilai ini menggambarkan besaran korelasi setiap indikator variabel. Peninjauan dilakukan dengan melihat nilai outer loading factor nya.

Tabel 1. Hasil Uji Loading Factor

\begin{tabular}{|c|c|c|c|c|c|c|}
\hline Indikator & PE & EE & SI & FC & BI & UB \\
\hline PE1 & 0.883 & & & & & \\
\hline PE2 & 0.811 & & & & & \\
\hline PE3 & 0.872 & & & & & \\
\hline PE4 & 0.804 & & & & & \\
\hline PE5 & 0.810 & & & & & \\
\hline EE1 & & 0.920 & & & & \\
\hline EE2 & & 0.948 & & & & \\
\hline EE3 & & 0.926 & & & & \\
\hline SI1 & & & 0.879 & & & \\
\hline SI2 & & & 0.856 & & & \\
\hline SI3 & & & 0.900 & & & \\
\hline FC1 & & & & 0.814 & & \\
\hline FC2 & & & & 0.889 & & \\
\hline FC3 & & & & 0.874 & & \\
\hline BI1 & & & & & 0.900 & \\
\hline BI2 & & & & & 0.905 & \\
\hline BI3 & & & & & 0.913 & \\
\hline UB1 & & & & & & 0.880 \\
\hline UB2 & & & & & & 0.888 \\
\hline
\end{tabular}




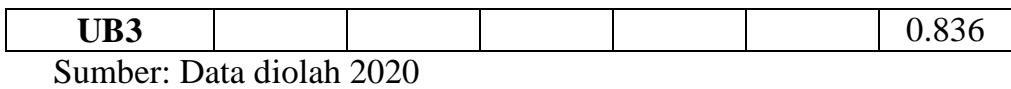

Berdasarkan data dalam tabel tersebut, diketahui bahwa seluruh indikator dalam penelitian ini menunjukkan nilai loading factor yang lebih besar dari 0.7, sehingga dianggap valid untuk digunakan mengukur variabel dalam penelitian ini.

\section{Uji Internal Consistency Reliability}

Pada tahapan pengujian ini, peneliti melihat nilai Composite Reliability (CR) setiap variabel yang digunakan.

Tabel 2. Hasil Uji Composite Reliability

\begin{tabular}{|l|c|}
\hline \multicolumn{1}{|c|}{ Variable } & Composite Reliability \\
\hline Performance Expectancy & 0.897 \\
\hline Effort Expectancy & 0.946 \\
\hline Social Influence & 0.839 \\
\hline Facilitating Condition & 0.889 \\
\hline Behavioral Intention & 0.924 \\
\hline Use Behavior & 0.895 \\
\hline Sumber: Data diolah 2020
\end{tabular}

Data dalam tabel tersebut menunjukkan bahwa semua variabel dalam penelitian ini mempunyai nilai $\mathrm{CR}$ lebih besar dari 0.7 sehingga semua variabel tersebut dinyatakan memenuhi syarat untuk digunakan dalam penelitian.

\section{Uji Average Variance Extracted}

Dalam tahapan pengujian ini, peneliti melihat nilai Average Variance Extracted (AVE) yang menunjukkan besaran varian atau keragaman indikator dari setiap variabel.

Tabel 3. Hasil Uji Average Variance Extracted

\begin{tabular}{|l|c|}
\hline \multicolumn{1}{|c|}{ Variable } & Average Variance Extracted \\
\hline Performance Expectancy & 0.635 \\
\hline Effort Expectancy & 0.784 \\
\hline Social Influence & 0.565 \\
\hline Facilitating Condition & 0.729 \\
\hline Behavioral Intention & 0.801 \\
\hline Use Behavior & 0.740 \\
\hline Sumber: Data diolah, 2020
\end{tabular}

Dari tabel diketahui bahwa nilai AVE setiap variabel dalam penelitian ini lebih besar dari nilai minimum 0.5, sehingga dapat disimpulkan semua variabel tersebut memenuhi syarat untuk digunakan dalam penelitian ini. 


\section{Uji Discriminant Validity}

Tahapan pengujian ini dilakukan dengan metode cross loading, dengan membandingkan hubungan indikator dengan konstruk/variabelnya dan dengan konstruk blok lain.

Tabel 4. Hasil Uji Discriminant Validity

\begin{tabular}{|c|c|c|c|c|c|c|}
\hline Indikator & PE & EE & SI & FC & BI & UB \\
\hline PE1 & 0.883 & 0.588 & 0.337 & 0.256 & 0.532 & 0.620 \\
\hline PE2 & 0.811 & 0.604 & 0.199 & 0.223 & 0.527 & 0.642 \\
\hline PE3 & 0.872 & 0.627 & 0.290 & 0.249 & 0.548 & 0.780 \\
\hline PE4 & 0.804 & 0.642 & 0.376 & 0.092 & 0.778 & 0.775 \\
\hline PE5 & 0.810 & 0.620 & 0.597 & 0.112 & 0.604 & 0.588 \\
\hline EE1 & 0.633 & 0.920 & 0.595 & 0.211 & 0.344 & 0.823 \\
\hline EE2 & 0.593 & 0.948 & 0.135 & 0.620 & 0.432 & 0.348 \\
\hline EE3 & 0.610 & 0.926 & 0.644 & 0.642 & 0.274 & 0.734 \\
\hline SI1 & 0.235 & 0.165 & 0.879 & 0.627 & 0.433 & 0.438 \\
\hline SI2 & 0.317 & 0.588 & 0.856 & 0.565 & 0.446 & 0.455 \\
\hline SI3 & 0.608 & 0.685 & 0.900 & 0.776 & 0.359 & 0.745 \\
\hline FC1 & 0.363 & 0.029 & 0.695 & 0.814 & 0.296 & 0.734 \\
\hline FC2 & 0.527 & 0.620 & 0.713 & 0.889 & 0.286 & 0.478 \\
\hline FC3 & 0.112 & 0.537 & 0.588 & 0.874 & 0.396 & 0.745 \\
\hline BI1 & 0.584 & 0.497 & 0.594 & 0.898 & 0.900 & 0.634 \\
\hline BI2 & 0.537 & 0.604 & 0.082 & 0.777 & 0.905 & 0.324 \\
\hline BI3 & 0.216 & 0.630 & 0.713 & 0.676 & 0.913 & 0.743 \\
\hline UB1 & 0.693 & 0.281 & 0.688 & 0.354 & 0.627 & 0.880 \\
\hline UB2 & 0.082 & 0.206 & 0.604 & 0.476 & 0.445 & 0.888 \\
\hline UB3 & 0.275 & 0.586 & 0.608 & 0.387 & 0.387 & 0.836 \\
\hline SEmber & ditan & 2020 & & & &
\end{tabular}

Sumber: data diolah, 2020

Berdasarkan data dalam tabel tersebut, diketahui bahwa nilai loading factor pada semua indikator di konstruknya lebih besar dari nilai pada konstruk lainnya. Hal ini berarti tidak ada masalah dalam pengujian ini dan tahap pengujian selanjutnya dapat dilakukan.

\section{Analisis Struktur Model (Inner Model)}

\section{Uji Path Coefficient ( $\beta$ )}

Pengujian ini dimaksudkan untuk melihat apakah jalur (path) pada model dalam penelitian memiliki pengaruh signifikan atau tidak.

Tabel 5. Hasil Uji Path Coefficient ( $\beta$ )

\begin{tabular}{|c|c|}
\hline Hubungan antar Variabel & Path Coefficient $(\boldsymbol{\beta})$ \\
\hline $\mathrm{PE} \rightarrow \mathrm{BI}$ & 0.259 \\
\hline $\mathrm{EE} \rightarrow \mathrm{BI}$ & 0.094 \\
\hline $\mathrm{SI} \rightarrow \mathrm{BI}$ & 0.177 \\
\hline $\mathrm{FC} \rightarrow \mathrm{UB}$ & 0.233 \\
\hline $\mathrm{BI} \rightarrow \mathrm{UB}$ & 0.370 \\
\hline
\end{tabular}

Sumber: data diolah 2020 
Data dalam tabel tersebut menunjukkan bahwa dari lima jalur (path) dalam model yang digunakan, ditemukan satu jalur (path) yang nilainya lebih kecil dari 0.1, yaitu EE-BI. Hal ini berarti jalur tersebut memiliki pengaruh yang tidak signifikan. Ke empat jalur lainnya menunjukkan pengaruh yang signifikan karena memiliki nilai di atas 0.1.

\section{Uji Coefficient of Determination (R square)}

Pengujian ini bertujuan untuk menjelaskan varian dari setiap variabel dependen atau variabel dipengaruhi yang digunakan dalam penelitian.

Tabel 6. Hasil Uji Coefficient of Determination (R square)

\begin{tabular}{|l|c|}
\hline \multicolumn{1}{|c|}{ Variabel } & R-Square \\
\hline Behavioral Intention & 0.764 \\
\hline Use Behavior & 0.316 \\
\hline Sumber: data diolah 2020
\end{tabular}

Data dalam tabel tersebut menunjukkan variabel PE, EE, dan SI mampu menjelaskan variabel BI yang merupakan variabel dependennya dengan kuat yaitu sebesar $76,4 \%$. Sementara itu, variabel FC dan BI mampu menjelaskan variabel UB dengan moderat yaitu sebesar $31.6 \%$.

\section{Uji T-test}

Pengujian ini bertujuan untuk menguji hipotesis yang diajukan dalam penelitian ini. Pengujian menggunakan metode bootstrapping, dilakukan dengan uji two-tailed dengan tingkat signifikansi $5 \%$.

Tabel 7. Hasil Uji T-test

\begin{tabular}{|c|c|}
\hline Hubungan antar Variabel & T-test \\
\hline $\mathrm{PE} \rightarrow \mathrm{BI}$ & 4.277 \\
\hline $\mathrm{EE} \rightarrow \mathrm{BI}$ & 1.167 \\
\hline $\mathrm{SI} \rightarrow \mathrm{BI}$ & 2.270 \\
\hline $\mathrm{FC} \rightarrow \mathrm{UB}$ & 2.567 \\
\hline $\mathrm{BI} \rightarrow \mathrm{UB}$ & 3.165 \\
\hline
\end{tabular}

Sumber: data diolah 2020

Dari tabel di atas, diketahui bahwa dari kelima hipotesis yang diajukan, ditemukan satu hipotesis yang nilai $T$-test nya lebih kecil dari 1.96, yaitu EE-BI. Hal ini berarti bahwa hipotesis tersebut tidak dapat diterima. Selain itu, ke empat hipotesis lainnya yang diajukan dalam penelitian ini memiliki nilai $T$-test lebih besar dari 1.96, artinya dapat diterima.

\section{Uji Effect Size $\left(\boldsymbol{f}^{2}\right)$}

Pengujian ini bertujuan untuk melihat pengaruh satu variabel terhadap variabel lain pada model yang digunakan dalam penelitian ini. 
Tabel 8. Hasil Uji Effect Size $\left(f^{2}\right)$

\begin{tabular}{|c|c|c|c|c|c|}
\hline Hipotesis & \multirow{2}{*}{ Jalur } & \multicolumn{3}{|c|}{$\mathbf{f}^{2}$} & \multirow{2}{*}{ Keterangan } \\
\cline { 3 - 5 } & & $\mathbf{R}^{2}-\mathbf{i n}$ & $\mathbf{R}^{2}-\mathbf{e x}$ & $\Sigma \mathbf{f}^{2}$ & \\
\hline H.1 & PE $\rightarrow$ BI & 0.644 & 0.740 & 0.170 & menengah \\
\hline H.2 & EE $\rightarrow$ BI & 0.644 & 0.751 & 0.021 & kecil \\
\hline H.3 & SI $\rightarrow$ BI & 0.644 & 0.489 & 0.035 & kecil \\
\hline H.4 & FC $\rightarrow$ UB & 0.342 & 0.132 & 0.065 & kecil \\
\hline H.5 & BI $\rightarrow$ UB & 0.342 & 0.619 & 0.114 & kecil \\
\hline
\end{tabular}

Sumber: data diolah

Data dalam tabel tersebut menunjukkan bahwa dari kelima hipotesis yang diajukan dalam penelitian ini, hanya ada satu hipotesis yang menunjukkan variabel yang memberi pengaruh menengah, yaitu hipotesis pertama (PE-BI) dengan nilai $\mathrm{f}^{2}$ sebesar 0.170 (lebih besar dari 0.15). Empat hipotesis lainnya menunjukkan pengaruh variabel yang lemah

\section{Uji Predictive Relevance (Q square)}

Pengujian ini bertujuan untuk membuktikan bahwa variabel pada model digunakan dalam penelitian ini memiliki keterkaitan prediktif dengan variabel lainnya.

Tabel 9. Hasil Uji Predictive Relevance (Q square)

\begin{tabular}{|l|c|}
\hline \multicolumn{1}{|c|}{ Variabel } & Q-Square \\
\hline Behavioral Intention & 0.764 \\
\hline Use Behavior & 0.316 \\
\hline
\end{tabular}

Sumber: data diolah 2020

Data dalam tabel di atas menunjukkan bahwa kedua variabel dependen yang digunakan dalam penelitian ini memiliki nilai $Q$ square yang lebih besar dari 0 . Hal ini berarti kedua variabel dependen tersebut memiliki keterkaitan prediktif dengan variabel lain yang digunakan dalam penelitian ini.

\section{Uji Relative Impact $\left(q^{2}\right)$}

Pengujian ini bertujuan untuk mengukur pengaruh relatif dari keterkaitan prediktif satu variabel dengan variabel lain.

Tabel 10. Hasil Uji Relative Impact $\left(q^{2}\right)$

\begin{tabular}{|c|c|c|c|c|c|}
\hline \multirow{2}{*}{ Hipotesis } & \multirow{2}{*}{ Jalur } & \multicolumn{3}{|c|}{$\mathbf{q}^{\mathbf{2}}$} & \multirow{2}{*}{ Keterangan } \\
\cline { 3 - 5 } & & $\mathbf{Q}^{\mathbf{2}} \mathbf{- i n}$ & $\mathbf{Q}^{\mathbf{2}}-\mathbf{e x}$ & $\Sigma_{\mathbf{q}}{ }^{2}$ & \\
\hline H.1 & PE $\rightarrow$ BI & 0.540 & 0.573 & 0.046 & kecil \\
\hline H.2 & EE $\rightarrow$ BI & 0.540 & 0.546 & 0.004 & kecil \\
\hline H.3 & SI $\rightarrow$ BI & 0.540 & 0.320 & 0.019 & kecil \\
\hline H,4 & FC $\rightarrow$ UB & 0.184 & 0.087 & 0.035 & kecil \\
\hline H.5 & BI $\rightarrow$ UB & 0.184 & 0.417 & 0.064 & kecil \\
\hline
\end{tabular}

Dari data pada tabel di atas, hubungan variabel pada semua hipotesis menunjukkan pengaruh yang kecil. Tidak ada nilai $\mathrm{q}^{2}$ yang berada di sekitar 0.15 . 


\subsection{Pembahasan}

Pengujian model penelitian melalui analisis pengukuran model (outer model) menunjukkan hasil bahwa model dalam penelitian ini, secara statistic menunjukkan karakteristik yang baik. Hasil dari analisis struktur model (inner model) dipaparkan sesuai dengan pertanyaan penelitian sebagai berikut:

Hasil pengujian hipotesis 1 membuktikan bahwa PE berpengaruh positif terhadap BI dalam menggunakan platform crowdfunding sebagai alternatif pendanaan (H1 diterima). Hasil ini sejalan dengan hasil beberapa penelitian sebelumnya $[15,16,17]$. Namun, penelitian lain menemukan bahwa tidak ada pengaruh antara kedua variabel tersebut [18]. Dalam beberapa tahun terakhir, penggunaan platform crowdfunding memang menjadi perhatian bagi para pelaku usaha yang belum memenuhi syarat untuk mengajukan bantuan pendanaan melalui Bank. Perkembangan teknologi yang begitu cepat yang memberi kemudahan akses pada berbagai informasi membuat platform crowdfunding berkembang dan dikenal luas oleh masyarakat dengan cepat [19]. Hal ini lah yang mendorong niat pelaku usaha UMKM dan Startup untuk menggunakan platform ini, terlebih responden dalam penelitian ini memang didominasi berusia 20-30 tahun, yang tentu sangat aktif mengikuti tren teknologi saat ini.

Pengujian hipotesis 2 membuktikan bahwa EE tidak berpengaruh signifikan terhadap BI dalam menggunakan platform crowdfunding sebagai alternatif pendanaan (H2 ditolak). Hasil ini mendukung hasil dari penelitian sebelumnya [18] yang juga menemukan tidak ada pengaruh di antara kedua variabel tersebut. Berbeda dengan hal tersebut, hasil ini tidak sejalan dengan hasil penelitian lain [16], [17] yang membuktikan adanya pengaruh positif yang signifikan variabel EE terhadap BI. Meski kemudahan akses dan banyaknya penyedia layanan platform menjadi hal menarik dalam penggunaan platform ini, namun untuk alasan keamanan, beberapa aturan memang tetap harus dipenuhi baik oleh penyelenggara platform maupun pihak yang mengajukan bantuan pendanaan. Beberapa penyelenggara platform yang berada di bawah pengawasan Otoritas Jasa keuangan (OJK) bahkan diketahui menetapkan ketentuan-ketentuan yang cukup ketat dalam menyeleksi penerima bantuan dananya. Namun demikian, hal-hal tersebut tidak menurunkan niat penggunaan teknologi ini. Kondisi perekonomian Indonesia akibat pandemi Covid-19 belum lama ini juga menjadi faktor pendorong para pelaku UMKM dan Startup yang usahanya terdampak, untuk menggunakan platform crowdfunding sebagai alternatif mendapatkan bantuan pendanaan agar tetap mampu 
mempertahankan usaha mereka, terlepas dari besar atau tidaknya usaha yang diperlukan untuk menggunakan platform tersebut.

Hasil pengujian hipotesis 3 membuktikan bahwa SI berpengaruh signifikan terhadap BI dalam menggunakan platform crowdfunding sebagai alternatif pendanaan. Dalam platform crowdfunding, pihak penyelenggara aktif menampilkan progress pendanaan usahausaha/proyek-proyek yang menerima bantuan melalui layanan mereka, termasuk jumlah dana yang telah dikumpulkan untuk usaha-usaha tersebut. Hal ini tentu memberi kemudahan bagi para pelaku usaha UMKM dan Startup untuk melihat sendiri bagaimana sebuah usaha bisa sangat terbantu dengan adanya layanan tersebut. Selain itu, tren penggunaan layanan ini yang begitu berkembang dalam beberapa waktu terakhir tentu mendorong para pelaku usaha UMKM dan Startup untuk mengikuti jejak rekan atau orang-orang di sekitar yang telah berhasil mendapatkan bantuan pendanaan melalui platform crowdfunding ini.

Hasil pengujian hipotesis 4 membuktikan bahwa FC berpengaruh positif terhadap UB dalam menggunakan platform crowdfunding sebagai alternatif pendanaan. Hasil ini tidak sejalan dengan hasil penelitian sebelumnya yang tidak menemukan adanya pengaruh signifikan variabel FC terhadap penggunaan smartphone [20]. Tuntutan membuat campaign yang menarik saat mengajukan bantuan pendanaan menjadi salah satu alasan mengapa para pelaku usaha ini membutuhkan beberapa fasilitas yang memadai untuk dapat menggunakan layanan pada platform crowdfunding ini. Selain itu, jaringan internet tentu menjadi fasilitas utama yang dibutuhkan dalam penggunaan layanan tersebut.

Pengujian hipotesis 5 membuktikan bahwa BI berpengaruh positif terhadap UB dalam menggunakan platform crowdfunding sebagai alternatif pendanaan. Hasil ini mendukung hasil penelitian sebelumnya [20]. Dalam penggunaan platform crowdfunding, adanya niat untuk menggunakan yang kemudian didukung dengan kemudahan penggunaan teknologi dewasa ini disertai kemudahan akses informasi tentu sangat mendorong seseorang agar menggunakan layanan ini.

\section{KESIMPULAN}

Hasil analisis data dalam penelitian ini menunjukkan bahwa dari lima hipotesis yang diajukan, satu diantaranya tidak diterima. faktor Performance Expectancy (PE) dan Social Influence (SI) diketahui berpengaruh positif terhadap Behavioral Intention (BI) dalam penggunaan platform crowdfunding sebagai alternatif pendanaan, sementara faktor Effort Expectancy (EE) tidak berpengaruh signifikan. Selain itu, faktor Facilitating Condition (FC) 
dan Behavioral Intention (BI) diketahui berpengaruh positif terhadap Use Behavior (UB) para pelaku UMKM dan Startup dalam menggunakan platform crowdfunding. Penelitian ini tidak lepas dari adanya kekurangan/keterbatasan yang dapat mengurangi kualitas data penelitian. Sampel yang digunakan dalam penelitian ini masih terbilang sedikit jika dibandingkan dengan jumlah pelaku usaha UMKM dan Startup. Penyebaran kuesioner yang dilakukan secara tidak langsung memungkinkan adanya persepsi berbeda dari responden atas pernyataan-pernyataan yang ada dalam kuesioner.

\section{DAFTAR PUSTAKA}

[1] H. Alaydrus, "Revolusi Industri 4.0 Diyakini Mampu Dorong Pertumbuhan hingga 7\% pada 2030", Wired, 13 Maret 2019, [Online]. Tersedia: https://ekonomi.bisnis.com/read/20190313/9/899273/revolusi-industri-4.0diyakini-mampu-dorong-pertumbuhan-hingga-7-pada-2030. [Diakses: 10 Agustus 2019].

[2] D. C. Lantu, et al., "Pengembangan Model Peningkatan Daya Saing UMKM di Indonesia: Validasi Kuantitatif Model," Jurnal Manajemen Teknologi, vol. 15, no. 1, pp. 77-93, 2016, doi: 10.12695/jmt.2016.15.1.6.

[3] D. M. Haryanti dan I. Hidayah, "Potret UMKM Indonesia: Si Kecil yang Berperan Besar", Wired, 29 Juli 2019, [Online]. Tersedia: https://www.ukmindonesia.id/baca-artikel/62. [Diakses: 11 Agustus 2019].

[4] A. Prasetyo, "Kontribusi UMKM atas PDB Melesat", Wired, 8 November 2018, [Online]. Tersedia: https://mediaindonesia.com/read/detail/196360-kontribusiumkm-atas-pdb-melesat. [Diakses: 11 Agustus 2019].

[5] A. T. Syauqi, "Startup sebagai Digitalisasi Ekonomi dan Dampaknya Bagi Ekonomi Kreatif di Indonesia", Wired, 2016, [Online]. Tersedia: https://www.academia.edu/28733057/Startup_sebagai_Digitalisasi_Ekonomi_dan _Dampaknya_bagi_Ekonomi_Kreatif_di_Indonesia. [Diakses: 16 Agustus 2019].

[6] A. Yuliani, "Kemenkop UKM: 3,79 Juta UMKM Sudah Go Online", Wired 17 November 2017, [Online]. Tersedia: https://www.kominfo.go.id/content/detail/11526/kemenkop-ukm-379-juta-umkmsudah-go-online/0/sorotan_media. [Diakses: 10 Agustus 2019].

[7] M. A. Jaya, R. Ferdiana, dan S. Fauziati, "Analisis Faktor Keberhasilan Startup Digital Di Yogyakarta", Prosiding Seminar Nasional Teknologi dan Informatika Ke-4, 2017, pp. 167-173.

[8] D. S. F. Akbar, "Mendorong Crowdfunding Untuk Peningkatan Investasi di Indonesia", Wired, 2016, [Online]. Tersedia: 
https://www.kemenkeu.go.id/media/4369/mendorong-crowdfunding-untukpeningkatan-investasi-di-indonesia.pdf. [Diakses: 16 Agustus 2019].

[9] I. Jenik, T. Lyman, dan A. Nava, "Crowdfunding And Financial Inclusion", Consultative Group to Assist the Poor Working Paper, 2017. Tersedia: https://www.cgap.org/sites/default/files/Working-Paper-Crowdfunding-andFinancial-Inclusion-Mar-2017.pdf.

[10] E. Kirby dan S. Worner, "Crowdfunding: An Infant Industry Growing Fast", Staff Working Paper of the IOSCO Research Departement, 2014. Tersedia: https://www.iosco.org/research/pdf/swp/Crowd-funding-An-Infant-IndustryGrowing-Fast.pdf.

[11] E. M. Gerber, J. Hui, dan P. Kuo, "Crowdfunding: Why People Are Motivated to Post and Fund Projects on Crowdfunding Platforms", Proceedings of the ACM 2012 Conference on Computer Supported Cooperative Work, Washington, USA, Februari 2012.

[12] I. A. Aziz, Nurwahidin, dan I. Chailis, "Faktor-Faktor yang Mempengaruhi Masyarakat Menyalurkan Donasi Melalui Platform Crowdfunding Berbasis Online," Jurnal Syarikah vol. 5 no. 1, Juni 2019, pp. 94-108.

[13] V. Venkatesh, et al., "User Acceptance Of Information Technology: Toward A Unified View," Mis Quarterly vol. 27 no. 3, pp. 425-478, September 2003.

[14] H. Latan, Model Persamaan Struktural Teori Dan Implementasi Amos 21.0. Bandung: Alfabeta, Ltd. 2013.

[15] A. Hormati, "Pengujian Model Unified Theory Of Acceptance And Use Of Technology dalam Pemanfaatan Sistem Informasi Keuangan Daerah," Jurnal Akuntansi Multiparadigma, vol. 3, no. 1, April 2012, pp. 1-24.

[16] N. N. Mugni, dan B. Rikumahu, "Analisis Niat Perilaku Penggunaan E-Money Berbasis Chip Menggunakan Model Modifikasi UTAUT (Studi Kasus Pada Pengguna Flazz E-Money Di Kota Bandung)," Jurnal Mitra Manajemen vol. 3, no.5, Mei 2019, pp. 614-627.

[17] D. W. Jacob, dan I. Darmawan, "Extending The UTAUT Model to Understand the Citizens' Acceptance and Use Of Electronic Government in Developing Country: A Structural Equation Modeling Approach," Atlantis Highligths in Engineering, vol. 2, 2019, pp. 92-96.

[18] R. N. Mustaqim, A. Kusyanti, dan H. Aryadita, "Analisis Faktor-Faktor yang Memengaruhi Niat Penggunaan E-Commerce Menggunakan Model UTAUT (Unified Theory Acceptance And Use Of Technology)," Jurnal Pengembangan Teknologi Informasi dan Ilmu Komputer vol. 2, no. 7, Juli 2018, pp. 2584-2593. 
[19] A. Y. Nugroho, dan F. Rachmaniyah, "Fenomena Perkembangan Crowdfunding di Indonesia," Ekonika vol. 4, no. 1, April 2019, pp. 34-46, doi: 10.30737/ekonika.v4il.254.

[20] P. V. Shara dan T. Widodo, "Penerapan Model Unified Theory of Acceptance and Use of Technology (UTAUT) untuk Menganalisis Minat Pengguna Smartphone di Kota Bandung," Sosiohumanitas Journal vol. 20, no. 1, Maret 2018, pp. 70-83, doi: 10.36555/sosiohumanitas.v20i1.49. 